\title{
Growth regulators and substrates for Oncidium baueri Lindl. micropropagation
}

\section{Reguladores de crescimento e substratos para a micropropagação de Oncidium baueri Lindl.}

\author{
Daniele Brandstetter Rodrigues ${ }^{1 *}$; Michele Carla Nadal2; Samila Silva Camargo ${ }^{3}$; \\ Adriane Marinho de Assis ${ }^{4}$; Márcia Wullf Schuch; \\ Roberta Marins Nogueira Peil ${ }^{4}$; Ricardo Tadeu Faria ${ }^{5}$
}

\begin{abstract}
An adequate concentration of growth regulators as well as the replacement of agar by an alternative medium may be promising from practical and financial points of view to produce orchid plants by micropropagation. The objective of this work was to evaluate different concentrations of growth regulator and alternative substrates for agar replacement in culture medium for in vitro multiplication and rooting of Oncidium baueri. In the explant multiplication phase, two experimental factors were evaluated- various concentrations of 6-benzylaminopurine (BAP) $\left(0.0,1.0,2.0\right.$, and $\left.3.0 \mathrm{mg} \mathrm{L}^{-1}\right)$ and substrates (agar, vermiculite, and coconut fiber) added to MS medium. In the rooting phase, different concentrations of indole butyric acid (IBA) $\left(0.0,0.5,1.0\right.$, and $\left.1.5 \mathrm{mg} \mathrm{L}^{-1}\right)$ were added to culture medium containing the same substrate. Six months after the experiments were initiated, the survival percentage, number of leaves, shoots, and roots and length of the aerial part and the major root were evaluated. The results suggested that addition of $1.0 \mathrm{mg} \mathrm{L}^{-1} \mathrm{BAP}$ is necessary for the $O$. baueri in vitro multiplication phase, but IBA is not necessary in the rooting phase. For the substrate, vermiculite is not indicated as an agar replacement. In contrast, coconut fiber can be used in both multiplication and rooting phases of Oncidium baueri in vitro culture.
\end{abstract}

Key words: Orchid. Coconut fiber. Culture medium. Vermiculite.

\section{Resumo}

Na micropropagação de orquídeas, a concentração adequada de reguladores de crescimento, bem como a substituição do ágar por substratos alternativos no meio de cultura podem ser promissoras do ponto de vista da praticidade e da economia financeira para a obtenção de mudas. Assim, o objetivo do trabalho foi avaliar diferentes concentrações de reguladores de crescimento e substratos alternativos em substituição ao ágar no meio de cultura para a multiplicação e o enraizamento in vitro de Oncidium baueri. Na fase de multiplicação dos explantes, foram avaliados dois fatores: concentração de benzilaminopurina (BAP) $\left(0,0 ; 1,0 ; 2,0\right.$ e 3,0 $\left.\mathrm{mg} \mathrm{L}^{-1}\right)$ e substrato (ágar, vermiculita e fibra de coco) no meio de cultura MS e, no período de enraizamento, foram testadas concentrações de ácido indolbutírico (AIB) $(0,0 ; 0,5 ; 1,0$

\footnotetext{
${ }^{1}$ Discente do Curso de Doutorado do Programa de Pós-Graduação em Ciência e Tecnologia de Sementes, Universidade Federal de Pelotas, UFPel, Pelotas, RS, Brasil. E-mail: ufpelbrandstetter@hotmail.com

2 Discente do Curso de Graduação em Agronomia, UFPel, Pelotas, RS, Brasil. E-mail: michecn@gmail.com

${ }^{3}$ Discente do Curso de Doutorado, Programa de Pós-Graduação em Produção Vegetal, Universidade do Estado de Santa Catarina, UDESC, Lages, SC, Brasil. E-mail: samilasc@yahoo.com.br

${ }^{4}$ Profs., Departamento de Fitotecnia, UFPel, Pelotas, RS, Brasil. E-mail: agroadri@ig.com.br; marciaws@ufpel.edu.br; rmnpeil@ gmail.com

${ }_{5}$ Prof. Dr., Departamento de Agronomia, Universidade Estadual de Londrina, UEL, Londrina, PR, Brasil. E-mail: faria@uel.br

* Author for correspondence
} 
e 1,5 $\mathrm{mg} \mathrm{L}^{-1}$ ) nos mesmos substratos e meio de cultura. Após seis meses da instalação dos experimentos, foram avaliadas as variáveis: porcentagem de sobrevivência; número médio de folhas, brotações e raízes; comprimento da parte aérea e da maior raiz. Para a fase de multiplicação in vitro é necessário a utilização de BAP na concentração de $1,0 \mathrm{mg} \mathrm{L}^{-1}$; porém, para a fase de enraizamento a utilização do regulador de crescimento AIB é dispensável. Quanto aos substratos, a vermiculita não é indicada para substituir o ágar; entretanto, a fibra de coco pode ser usada, tanto na fase de multiplicação, quanto no enraizamento in vitro de Oncidium baueri.

Palavras-chave: Orquídea. Fibra de coco. Meio de cultura. Vermiculita.

\section{Introduction}

Oncidium baueri Lindl., popularly known as golden rain, belongs to a group of native orchids of Brazil. It is an ornamental species popular among consumers owing to its numerous yellow flowers distributed along the flower stem. It is commonly used in floriculture, marketed as a potted plant or cut flower, and for landscape projects (GARAY; STACY, 1974; LORENZI; SOUZA, 2001; FARIA et al., 2006).

Owing to their high ornamental potential, orchids have been suffering from increasing human exploitation. Thus, some species are threatened with extinction, because their multiplication by natural means is slow. Furthermore, their seeds are devoid of endosperm and have a low percentage of germination in nature (SORACE et al., 2008; JUNGHANS; SOUZA, 2013). Therefore, a promising alternative for the commercial production of seedlings is micropropagation, which results in the production of seedlings with high standards of quality and efficient use of space (FARIA et al., 2010, 2012).

Although micropropagation techniques are widely adopted for several species, additional information regarding the factors involved in the production of seedlings on a commercial level is required, owing to the high cost of the materials and equipment used, as well as low efficiency in the development and multiplication of some species. As a result, new approaches have been developed to enhance the outcome and reduce the costs of micropropagation technique (PEREIRA et al., 1999; PEREIRA; FORTES, 2003; PINHO, 2003).
In order to obtain satisfactory results in the stages of multiplication and in vitro rooting, strict control over light availability and hormonal balance in the culture medium are essential. The latter is one of the most relevant factors to the success of this technique. Therefore, in addition to the basic formulation of the culture media, the use of growth regulators is crucial for success of the propagation of in vitro cultures (SCHUCH; ERIG, 2005).

Another factor that affects the success of micropropagation is the use of agar (polysaccharide extracted from seaweed) as the gelling agent in the culture medium. In Brazil, because this material, used in large quantities, is imported, resulting in high costs for both research and commercial laboratories (FERRI et al., 1998; LIMA-NISHIMURA et al., 2003). According to Scholten and Pierik (1998), agar can influence the growth and development of in vitro cultures. Roots grown in culture media containing agar, in general, are not very efficient in absorbing nutrients and water during acclimation, resulting in high mortality of plants (HOFFMANN et al., 2001).

Several substrates, such as chopped polyurethane foam (FARIA et al., 2006), the mixture of carbonized rice shells and coconut fibers (ZANDONÁ et al., 2014), coconut powder and fibers (COLOMBO et al., 2005; ASSIS et al., 2008), and vermiculite (MORAES et al., 2002), have been tested in the cultivation of orchids. However, there is little information regarding the use of these materials as alternatives to agar in the culture medium.

To investigate the issues described above, the objective of this study was to evaluate different 
concentrations of growth regulators and alternative substrates to agar in the culture medium for the multiplication and in vitro rooting of Oncidium baueri.

\section{Methods and Materials}

The study was conducted from November 2013 to May 2014, in the Fruit Trees Plant Propagation Laboratory, Department of Plant Science, Faculty of Agronomy Eliseu Maciel (FAEM), Federal University of Pelotas, Pelotas (UFPel) - RS.

Oncidium baueri plants provided by Londrina State University (UEL), originating from vegetative propagation (six months after sowing), had an average of $2 \pm 0.3$ leaves and height of $5.6 \mathrm{~cm} \pm 0.3$. These plants were subcultured in clear glass bottles with transparent plastic covers with a capacity of $250 \mathrm{~mL}$ of MS liquid medium (MURASHIGE; SKOOG, 1962). At the first stage of the experiment, which refers to the multiplication of the explants (adventitious shoots), two factors were studied: concentrations of 6-benzylaminopurine (BAP) $(0.0$, 1.0, 2.0, and $3.0 \mathrm{mg} \mathrm{L}^{-1}$ ) and substrates (standard coconut fiber Amafibra ${ }^{\circledR}$ and vermiculite of average particle size) as gelling agents compared to agar (concentration of $6 \mathrm{~g} \mathrm{~L}^{-1}$ ), totaling 12 treatments with four replications and five explants used in each replicate. Six grams of substrate were added per vial plus the liquid culture medium $(30 \mathrm{~mL})$; this amount was set based on preliminary tests, which determined the minimum amount needed to support the plants in these containers. In the second stage during rooting, four concentrations of indole butyric acid (IBA) $\left(0.0,0.5,1.0\right.$, and $\left.1.5 \mathrm{mg} \mathrm{L}^{-1}\right)$ and the same substrates described above were tested. The design was completely randomized in a $4 \times 3$ factorial scheme for a total of twelve treatments with four replicates and five explants in each replicate.

The $\mathrm{pH}$ of the culture medium was adjusted to 5.8 before the addition of the agar (in the relevant treatment) at a concentration of $6.0 \mathrm{~g} \mathrm{~L}^{-1}$. The culture medium was autoclaved at $120{ }^{\circ} \mathrm{C}$ and 1.5 atm for $20 \mathrm{~min}$. After cooling, the bottles received explants and were transferred to a growth chamber with $16 \mathrm{~h}$ photoperiod, temperature $25 \pm 2{ }^{\circ} \mathrm{C}$, and light intensity of $27 \mu \mathrm{mol} \cdot \mathrm{m}^{-2} \mathrm{~s}^{-1}$ (Figure 1).

After six months, the following variables in both experiments were evaluated: survival percentage, number of leaves, shoots, and roots, and length of the aerial part and of the major root $(\mathrm{cm})$.

Data were evaluated with analysis of variance; means were compared with Tukey's test at 5\% probability using Winstat (MACHADO; CONCEIÇÃO, 2007). Percentage values were transformed using the square root of $\mathrm{x}+0.5$, where $\mathrm{x}$ is the percentage for each variable.

\section{Results and Discussion}

Table 1 shows the percentage survival of Oncidium baueri plantlets in the in vitro multiplication phase. No interactions were found between the factors; however, significant differences in the BAP concentrations were observed. The BAP concentration of $3.0 \mathrm{mg} \mathrm{L}^{-1}$ led to higher percentage survival than other concentrations, but did not differ statistically from the concentration of $1.0 \mathrm{mg} \mathrm{L}^{-1}$.

In the multiplication phase, the number of leaves (Table 2) was significantly lower in the substrate containing agar with a BAP concentration of $3.0 \mathrm{mg} \mathrm{L}^{-1}$ than in the other treatments. A similar result was found by Santos et al. (2010), who evaluated the effect of BAP concentration in the in vitro multiplication of Epidendrum ibaguense (epidendrum). They found a smaller number of leaves as BAP concentration increased from $2.0 \mathrm{mg}$ $\mathrm{L}^{-1}$. The number of leaves was significantly lower for vermiculite as a substrate when compared to agar for all BAP concentrations analyzed up to $2.0 \mathrm{mg}$ $\mathrm{L}^{-1}$, in contrast to coconut fiber, which, regardless of the concentration of this growth regulator, produced averages similar to or greater than the agar (Table 2 ). The negative effect of vermiculite contrasts with the results observed by Fialho et al. (2011), in which this substrate did not decrease the number of leaves in the micropropagation of laelia (Laelia tenebrosa Rolfe). 
Table 1. Mean values of the percentage survival of Oncidium baueri plants in the in vitro multiplication phase as a function of 6-benzylaminopurine (BAP) concentration and the substrate used as culture medium. Pelotas-RS, 2015.

\begin{tabular}{cc}
\hline Factor & Survival percentage (\%) \\
\hline BAP $\left(\mathbf{m g . L ^ { - 1 }}\right)$ & $65 \mathrm{~b}$ \\
$\mathbf{0 . 0}$ & $75 \mathrm{ab}$ \\
$\mathbf{1 . 0}$ & $65 \mathrm{~b}$ \\
$\mathbf{2 . 0}$ & $95 \mathrm{a}$ \\
$\mathbf{3 . 0}$ & \\
Substrate & $64^{* *}$ \\
Agar & 81 \\
Vermiculite & 80 \\
Coconut fiber & 33.11 \\
CV (\%) & \\
\hline
\end{tabular}

* Mean values followed by the same letter do not differ by Tukey's test at a $5 \%$ level of probability. ** Mean values do not differ by Tukey's test at a $5 \%$ level of probability.

Table 2. Number of leaves and roots of Oncidium baueri explants in the in vitro multiplication phase as a function of 6-benzylaminopurine (BAP) concentration and the substrate used as culture medium. Pelotas - RS, 2015.

\begin{tabular}{|c|c|c|c|c|c|c|}
\hline \multirow[b]{2}{*}{$\begin{array}{c}\text { BAP } \\
\left(\mathrm{mg} . \mathrm{L}^{-1}\right)\end{array}$} & \multicolumn{3}{|c|}{$\begin{array}{c}\text { Number of Leaves } \\
\text { Substrate }\end{array}$} & \multicolumn{3}{|c|}{$\begin{array}{c}\text { Number of Roots } \\
\text { Substrate }\end{array}$} \\
\hline & Agar & Vermiculite & $\begin{array}{l}\text { Coconut } \\
\text { Fiber }\end{array}$ & Agar & Vermiculite & $\begin{array}{c}\text { Coconut } \\
\text { Fiber }\end{array}$ \\
\hline 0.0 & $4.33 \mathrm{ABa}^{*}$ & $2.72 \mathrm{Ab}$ & $4.10 \mathrm{Aa}$ & $2.00 \mathrm{Ba}$ & $1.33 \mathrm{Ab}$ & $2.20 \mathrm{ABa}$ \\
\hline 1.0 & $4.74 \mathrm{Aa}$ & $3.00 \mathrm{Ab}$ & $4.23 \mathrm{Aa}$ & $3.13 \mathrm{Aa}$ & $1.63 \mathrm{Ac}$ & $2.58 \mathrm{Ab}$ \\
\hline 2.0 & $4.41 \mathrm{ABa}$ & $2.76 \mathrm{Ab}$ & $4.04 \mathrm{Aa}$ & $2.55 \mathrm{Ba}$ & $1.69 \mathrm{Ab}$ & $2.26 \mathrm{ABa}$ \\
\hline 3.0 & $3.75 \mathrm{Bb}$ & $3.33 \mathrm{Ab}$ & $4.84 \mathrm{Aa}$ & $2.33 \mathrm{Ba}$ & $1.50 \mathrm{Ab}$ & $1.98 \mathrm{Bab}$ \\
\hline CV (\%) & 29.29 & & & & 31.85 & \\
\hline
\end{tabular}

* Means followed by the same letter, upper case within a column and lower case within a line, do not differ by Tukey's test at a $5 \%$ level of probability.

The number of leaves is an important variable for the growth and development of plants, since through photosynthesis, $\mathrm{CO}_{2}$ and light energy penetrate the leaf surface; further, through transpiration, the stimulation for the intake of water and nutrients from the root medium to the plant occurs. Thus, a higher number of leaves were associated with a higher metabolism, growth, and development of the plant (BENINCASA; LEITE, 2002). Studies carried out with banana seedlings in vitro by Santos et al. (2004) found that the seedlings with the largest number of leaves had a higher fruit set index, initial growth, and development in the acclimatization stage, owing to the increased production of photoassimilates, possibly resulting in increased production. For the number of roots in the multiplication phase (Table 2), only the concentration of $1.0 \mathrm{mg} \mathrm{L}^{-1} \mathrm{BAP}$ produced more roots than the others in the agar cultivation. In the case of vermiculite, there were no significant differences between the concentrations of BAP. In contrast, for the coconut fiber up to a concentration of $2.0 \mathrm{mg} \mathrm{L}^{-1}$, no differences were found; however, the larger concentration of BAP resulted in a reduction in root number when compared to a concentration of $1.0 \mathrm{mg} \mathrm{L}^{-1}$. In general, the coconut fiber substrate, without the addition of the regulator and cultivation in agar with $1.0 \mathrm{mg} \mathrm{L}^{-1}$ of BAP, showed promising results for the variable number of roots. This variable is very important regarding the growth and development of seedlings, as an undeveloped root system reduces the leaf area and height and biomass production (OLIVEIRA et al., 2008). 
For the length of the aerial part in the multiplication phase (Table 3), there was no significant interaction between the two factors. Evaluating the effect of BAP concentration, the greatest length was obtained with a BAP concentration of $2.0 \mathrm{mg} \mathrm{L}^{-1}$ which did not differ from concentrations of 0.0 and $3.0 \mathrm{mg} \mathrm{L}^{-1}$ but was greater than a concentration of $1.0 \mathrm{mg} \mathrm{L}^{-1}$. In a study of micropropagation of miniature roses, Rosa chinensis Jacq, performed by Diniz et al. (2014), an increased length of the aerials parts with a BAP concentration of $1.0 \mathrm{mg} \mathrm{L}^{-1}$ was obtained. Regarding the substrate used in the culture medium, coconut fiber produced length of aerial parts greater than vermiculite and agar. In a study conducted by Faria et al. (2006), the highest value for this variable was found in an alternative substrate to agar, chopped foam.

Table 3. Aerial parts length, number of shoots, and root length in explants of Oncidium baueri in the in vitro multiplication phase as a function of the concentration of 6-benzylaminopurine (BAP) and the substrate used as culture medium. Pelotas - RS, 2015.

\begin{tabular}{cccc}
\hline $\begin{array}{c}\text { Factor } \\
\text { BAP }\left(\mathbf{m g ~ ~ L ^ { - 1 }}\right)\end{array}$ & Aerial parts length $(\mathbf{c m})$ & Number of shoots & Root Length (cm) \\
\hline $\mathbf{0 . 0}$ & $2.40 \mathrm{AB}$ & $1.67 \mathrm{~A}$ & \\
$\mathbf{1 . 0}$ & $2.36 \mathrm{~B}$ & $1.77 \mathrm{~A}$ & $1.22 \mathrm{~A}$ \\
$\mathbf{2 . 0}$ & $2.79 \mathrm{~A}$ & $1.52 \mathrm{~A}$ & $1.34 \mathrm{~A}$ \\
$\mathbf{3 . 0}$ & $2.42 \mathrm{AB}$ & $1.61 \mathrm{~A}$ & $1.10 \mathrm{~A}$ \\
Substrate & & & \\
Agar & $2.60 \mathrm{~B} *$ & $1.74 \mathrm{~A}$ & $1.79 \mathrm{~A}$ \\
Vermiculite & $1.89 \mathrm{C}$ & $1.41 \mathrm{~B}$ & $0.65 \mathrm{C}$ \\
Coconut Fiber & $2.99 \mathrm{~A}$ & $1.77 \mathrm{~A}$ & $1.33 \mathrm{~B}$ \\
CV $(\%)$ & 36.29 & 35.53 & 67.45 \\
\hline
\end{tabular}

* Means followed by the same letter do not differ by Tukey's test at a $5 \%$ level of probability.

For the number of shoots in the multiplication phase (Table 3), there was no interaction between the factors. The different concentrations of BAP exerted no significant effect on this variable, unlike the results observed by Soares (2009) with an orchid hybrid [(Laelia cattleya Culminant 'Tuilerie' $\mathrm{x}$ Laelia cattleya Sons Atout Rotunda) x Brassolaelia cattleya Startifire Moon Beach], in which the best results for this variable (2.35) were obtained with a concentration of $2.0 \mathrm{mg} \mathrm{L}^{-1}$. However, with respect to substrates, vermiculite had a negative effect and coconut fiber was similar to agar for number of shoots.

Similarly, for the root length in the multiplication phase (Table 3), interaction between the factors and significant effects of BAP concentrations were not found. However, when effect of the substrate was examined, agar produced the greatest root length followed by the coconut fiber and lastly the vermiculite. This response contradicts the results of Faria et al. (2006), in which the use of agar did not affect the root length in in vitro cultures of Oncidium baueri.

The analysis of the variables evaluated in the second experiment of this study, which deals with the rooting of explants of Oncidium baueri, indicates that there was no interaction and no significant effect of the concentration of IBA and substrate on the percentage survival of the explants at this stage (Table 4). 
Table 4. Mean percentage survival of Oncidium baueri plants in the in vitro rooting stage depending on the concentration of indolebutyric acid (IBA) and the substrate used as culture medium. Pelotas-RS, 2015.

\begin{tabular}{ccccc}
\hline & \multicolumn{3}{c}{ Percentage of Survival (\%) } \\
IBA (mg.L $\left.\mathbf{H}^{-1}\right)$ & $\mathbf{1 . 0}$ & $\mathbf{1 . 5}$ \\
\hline Substrate & $\mathbf{0 . 0}$ & $\mathbf{0 . 5}$ & 80 & 75 \\
Agar & $65^{*}$ & 90 & 75 & 90 \\
Vermiculite & 90 & 80 & 95 & 85 \\
Coconut Fiber & 65 & 85 & 32.88 & \\
CV (\%) & & & \\
\hline
\end{tabular}

* Means do not differ by Tukey's test at a $5 \%$ level of probability.

Analysis of variance indicated that there was an interaction between the factors for the variable aerial part length in the rooting stage. There were no significant differences between the IBA concentrations for explants cultured on agar and coconut fiber (Table 5). However, higher concentrations than those used in this work might be detrimental to the aerial part length, since Santos et al. (2010), in an experiment with epidendrum (Epidendrum ibaguense Kunth), observed the largest average of $6.76 \mathrm{~cm}$ with a concentration of $1.6 \mathrm{mg}$ $\mathrm{L}^{-1}$. In contrast, for the culture with vermiculite, they found that at the highest concentration of IBA, the aerial part length was higher when compared to other concentrations. Furthermore, it was reported that there were substrate effects only when the medium contained $1.0 \mathrm{mg} \mathrm{L}^{-1} \mathrm{IBA}$, whereas the orchid plants grown in coconut fiber produced aerial part lengths similar to agar and greater than vermiculite.

Table 5. Length of the aerial part of Oncidium baueri explants in the in vitro rooting stage owing to the concentration of indolebutyric acid (IBA) and substrate used as growth medium. Pelotas - RS, 2015.

\begin{tabular}{cccc}
\hline & \multicolumn{3}{c}{ Aerial parts length $(\mathbf{c m})$} \\
Substrate \\
IBA $\left(\mathbf{m g . L}^{-\mathbf{1}}\right)$ & Agar & Vermiculite & Coconut Fiber \\
$\mathbf{0 . 0}$ & $2.02 \mathrm{Aa}^{*}$ & $2.05 \mathrm{ABa}$ & $3.45 \mathrm{Aa}$ \\
$\mathbf{0 . 5}$ & $2.75 \mathrm{Aa}$ & $3.85 \mathrm{Aa}$ & $2.53 \mathrm{Aa}$ \\
$\mathbf{1 . 0}$ & $3.35 \mathrm{Aab}$ & $2.21 \mathrm{ABb}$ & $4.26 \mathrm{Aa}$ \\
$\mathbf{1 . 5}$ & $2.67 \mathrm{Aa}$ & $1.64 \mathrm{Ba}$ & $2.68 \mathrm{Aa}$ \\
$\mathbf{C V}(\mathbf{\%})$ & & 35.99 & \\
\hline
\end{tabular}

* Means followed by the same letter, upper case within a column and lower case within a line, do not differ by Tukey's test at a $5 \%$ level of probability.

No significant effect of IBA concentration was found in the rooting stage for the variables number of leaves, number of shoots, shoot length, and number of roots (Table 6). Thus, our results suggest that for the in vitro rooting of Oncidium baueri the addition of IBA is not necessary.

In the range between 0.0 and $1.5 \mathrm{mg} \mathrm{L}^{-1} \mathrm{IBA}$, no effect of this regulator on the number of leaves (Table
6) was found. Silva et al. (2013), however, observed a negative effect of increasing the concentration of IBA (between 1.0 and $4.0 \mathrm{mg} \mathrm{L}^{-1}$ ) on the number of cyrtopodium leaves (Cyrtopodium saintlegerianum $\mathrm{Rchb}$ ). This reduction can be attributed to the phytotoxic effects that synthetic auxins might exert at high concentrations, being used as herbicides in crops in some cases (MERCIER, 2012). 
Table 6. Number of leaves and shoots, shoot length, and number of roots in Oncidium baueri explants in the in vitro rooting phase in relation to the concentration of indolebutyric acid (IBA) and substrate used as culture medium. Pelotas - RS, 2015.

\begin{tabular}{ccccc}
\hline $\begin{array}{c}\text { Factor } \\
\left.\text { IBA (mg. } \mathbf{L}^{-\mathbf{1}}\right)\end{array}$ & Number of Leaves & Number of shoots & Shoots Length $(\mathbf{c m})$ & Number of Roots \\
\hline $\mathbf{0 . 0}$ & $3.79 \mathrm{~A}$ & $1.53 \mathrm{~A}$ & $1,45 \mathrm{~A}$ & $2.20 \mathrm{~A}$ \\
$\mathbf{0 . 5}$ & $3.81 \mathrm{~A}$ & $1.56 \mathrm{~A}$ & $1,68 \mathrm{~A}$ & $2.17 \mathrm{~A}$ \\
$\mathbf{1 . 0}$ & $3.62 \mathrm{~A}$ & $1.54 \mathrm{~A}$ & $1,64 \mathrm{~A}$ & $2.26 \mathrm{~A}$ \\
$\mathbf{1 . 5}$ & $3.67 \mathrm{~A}$ & $1.50 \mathrm{~A}$ & $1,49 \mathrm{~A}$ & $2.17 \mathrm{~A}$ \\
Substrate & & & & \\
Agar & $4.05 \mathrm{~A}$ & $1.68 \mathrm{~A}$ & $2.33 \mathrm{~A}$ & $2.52 \mathrm{~A}$ \\
Vermiculite & $3.15 \mathrm{~B}$ & $1.31 \mathrm{~B}$ & $0.90 \mathrm{~B}$ & $1.79 \mathrm{~B}$ \\
Coconut Fiber & $3.96 \mathrm{~A}$ & $1.60 \mathrm{~A}$ & $1.46 \mathrm{~B}$ & $2.29 \mathrm{~A}$ \\
CV (\%) & 16.68 & 19.68 & 49.63 & 20.24 \\
\hline
\end{tabular}

* Means followed by the same letter do not differ by Tukey's test at a 5\% level of probability.

With respect to the effect of the substrate, the presence of vermiculite in the cultivation led to a reduction in the number of leaves and shoots, length of shoots, and number of roots in the rooting stage. In contrasts, coconut fiber produced similar results to agar for all of these variables, except for the number of shoots (Table 5) and length of shoots (Table 6), which were lower in this substrate when compared to agar. The results obtained differ from those of Fialho et al. (2011), who reported no significant differences in the number of leaves between agar, vermiculite, and coconut fiber media used for in vitro rooting of pteridium (Pteridium aquilinum Kuhn), and from those of Gallo et al. (2014), who reported no significant differences between agar and filter paper and polyurethane foam with respect to their the function of rooting cattleya (Cattleya loddigesii). Thus, the addition of the IBA growth regulator in the rooting phase did not improve the response of the variables analyzed in the in vitro culture of Oncidium baueri (Tables 4 to 6). This lack of effect is as a great advantage from the economic point of view of seedling production of this species because, by not using growth regulator at this stage, it reduces the costs of using in vitro culture. However, analysis of the survival percentages of the multiplication stage strongly supports that the use of a concentration of $1.0 \mathrm{mg} \mathrm{l}^{-1} \mathrm{BAP}$ is required.
Regarding the substrates, both vermiculite and coconut fiber are materials of lower cost than agar and can be purchased in the south region of Brazil. Both have the important characteristic of not deteriorating during in vitro cultivation (which would invalidate their use as viable gelling agent alternatives). Golle et al. (2010) emphasized the importance of this aspect when arguing against the use of cornstarch, for example, due to the release of $\alpha$-amylase by the roots of some species.

Although the alternatives to agar substrates did not produce a negative effect on the percentage survival both in the multiplication (Table 1) and the rooting stages (Table 4), vermiculite reduced the responses obtained for most variables in both stages (Tables 2, 3 and 6). In contrast, coconut fiber produced very similar results to the agar in all the parameters evaluated in the explants (Tables 2, 3, 5 and 6), with the exception of shorter shoots lengths in the rooting phase (Table 6). This result may be related to the higher water retention capacity of vermiculite, which might have caused greater contact between the solution and the plant base tissues, stimulating enzymatic reactions responsible for the occurrence of necrosis. Another possibility is the occurrence of such reactions in tissues responsible for the formation of root primordia, due to the $\mathrm{pH}$ value of this substrate (PEREIRA et al., 2005). 


\section{Conclusions}

1. The use of BAP at a concentration of $1.0 \mathrm{mg}$ $\mathrm{L}^{-1}$ is recommended for the in vitro multiplication phase of Oncidium baueri.

2. The use of the auxin IBA is not necessary in the in vitro rooting phase of Oncidium baueri.

3. The in vitro multiplication and rooting of explants of Oncidium baueri may be performed in MS medium containing coconut fiber as a gelling agent to replace agar.

\section{Acknowledgments}

We thank the Coordination for the Improvement of Higher Education Personnel (CAPES) for financial support and Londrina State University for supplying plant material.

\section{References}

ASSIS, A. M. D.; FARIA, R. T. D.; UNEMOTO, L. K.; COLOMBO, L. A. Cultivo de Oncidium baueri Lindley (Orchidaceae) em substratos a base de coco. Ciência e Agrotecnologia, Lavras, v. 32, n. 3, p. 981-985, maio/jun. 2008. Disponível em: <http:// www.scielo.br/scielo.php?script $=$ sci_arttext\&pid $=$ S1413-70542008000300042 $>$. Acesso em: 19 jan. 2015.

BENINCASA, M. M. P.; LEITE, I. C. Fisiologia vegetal. Jaboticabal: Funep, 2002. 168 p.

COLOMBO, L. A.; FARIA, R. T.; ASSIS, A. M.; FONSECA, I. C. B. Aclimatização de um híbrido de Cattleya em substratos de origem vegetal sob dois sistemas de irrigação. Acta Scientiarum Agronomy, Maringá, v. 27, n. 1, p. 145-150, 2005. Disponível em: $<$ file:///C:/Users/Dani/Downloads/2134-5753-1-PB. pdf $>$. Acesso em: 19 jan. 2015.

DINIZ, N.; ALMEIDA, J. L.; OLIVEIRA, A. B.; VIDAL, F. R. Multiplicação e enraizamento in vitro de Minirosa. Revista Ciência Agronômica, Fortaleza, v. 45, n. 1, p. 68-73, jan./mar. 2014. Disponível em: <file:///C:/ Users/Dani/Downloads/1726-14570-1-PB.pdf>. Acesso em: 20 jan. 2015.
FARIA, R. T.; ASSIS, A. M. A.; FIÚZA, J. R. P. C. Cultivo de orquídeas. Londrina: Mecenas, 2010. 2008 p.

FARIA, R. T.; ASSIS, A. M. A.; UNEMOTO, L. K.; FIÚZA, J. R. P. C. Produção de orquídeas em laboratório. Londrina: Mecenas, 2012. 124 p.

FARIA, R. T.; DALIO, R. J. D.; UNEMOTO, L. K.; SILVA, G. L. Propagação in vitro de Oncidium baueri Lindl. (Orchidaceae) sem uso de ágar. Acta Scientiarum Agronomy, Maringá, v. 28, n. 1, p. 71-74, jan./mar. 2006. Disponível em: <http://www.redalyc.org/ pdf/3030/303026568017.pdf>. Acesso em: 20 jan. 2015.

FERRI, V. C.; CENTELlAS, A. Q.; HELBIG, V. E.; FORTES, G. R. L. Uso de ágar, amido e ácido indolbutírico no enraizamento in vitro do porta-enxerto de macieira MM 111. Ciência Rural, Santa Maria, v. 28, n. 4, p. 561-565, 1998. Disponível em: <http://www. scielo.br/pdf/cr/v28n4/a05v28n4.pdf>. Acesso em: 21 jan. 2015.

FIALHO, G. S.; VALE, J. C.; SOBREIRA, F. M.; SCHMIDT, E. R. Comportamento de plântulas de Laelia tenebrosa Rolfe (Orchidaceae), inoculadas in vitro sob diferentes substratos. Arica, v. 29, n. 1, p. 103-105, 2011.

GARAY, L. A.; STACY, J. E. Synopsis of the genus Oncidium. Bradea, Rio de Janeiro, v. 1, n. 40, p. 393427, 1974.

GALLO, F. R.; KUHN, B. C.; GUTIERRE, M. A. M. Cultivo in vitro de Cattleya loddigesii (Orchidaceae) sobre suportes alternativos ao ágar. SaBios: Revista de Saúde e Biologia, Campo Mourão, v. 9, n. 3, p. 1722, out./dez. 2014. Disponível em: <http://revista. grupointegrado.br/revista/index.php/sabios2/article/ view/1450/626>. Acesso em: 19 jan. 2015.

GOLLE, D. P.; REINIGER, L. R.; CURTI, A. R.; HANAUER, J. G.; WALDOW, D. A. G. Substratos alternativos e tratamentos pré-germinativos na germinação in vitro de sementes de Pinus taeda $\mathrm{L}$. Revista Árvore, Viçosa, MG, v. 34, n. 1, p. 39-48, 2010. Disponível em: <http://www.scielo.br/pdf/rarv/v34n1/ v34n1a05>. Acesso em: 20 jan. 2015.

HOFFMANN, A.; PASQUAL, M.; CHALFUN, N. N.; VIEIRA, S. S. N. Substratos na indução e desenvolvimento in vitro de raízes em dois porta-enxertos de macieira. Pesquisa Agropecuária Brasileira, Brasília, v. 36, n. 11, p. 1371-1379, nov. 2001. Disponível em: <http://www. scielo.br/pdf/pab/v36n11/6810.pdf>. Acesso em: 20 jan. 2015. 
JUNGHANS, T. G.; SOUZA, A. S. Aspectos práticos da micropropagação de plantas. 2. ed. Brasília: Embrapa, 2013. 407 p.

LIMA-NISHIMURA, N.; QUOIRIN, M.; NADDAF, Y. G. A xyloglucan from seeds of the native Brazilian species Hymenaea courbaril for micropropagation of Marubakaido and Jonagored apples. Plant Cell Reports, New York, v. 21, n. 5, p. 402-407, 2003.

LORENZI, H.; SOUZA, H. M. Plantas ornamentais no Brasil. 3. ed. Nova Odessa: Instituto Plantarum, 2001. $1088 \mathrm{p}$.

MACHADO, A. A.; CONCEIÇÃO, A. R. Sistema de análise estatística para Windows. Winstat. Versão, v. 2. UFPel, 2007.

MERCIER, H. Auxinas. In: KERBAUY, G. B. (Ed.). Fisiologia vegetal. Rio de Janeiro: Guanabara Koogan, 2012. $431 \mathrm{p}$.

MORAES, L. M.; CAVALCANTE, L. C. D.; FARIA, R. T. Substratos para aclimatização de plântulas de Dendrobium nobile Lindl. (Orchidaceae) propagadas in vitro. Acta Scientiarum Agronomy, Maringá, v. 24, n. 5, p. 1397-1400, 2002. Disponível em: <file://C:/Users/ Dani/Downloads/2429-8195-1-PB\%20(1).pdf>. Acesso em: 7 dez. 2014.

MURASHIGE, T.; SKOOG, F. A revised medium for rapid growth and bioassay with tobacco tissue cultures. Physiologia Plantarum, Riverside, v. 15, n. 3, p. 473497, 1962.

OLIVEIRA, J. P.; COSTA, F. H. S.; PEREIRA, J. E. S. Crescimento de mudas micropropagadas de bananeira aclimatizadas nas condições da Amazônia Sul Ocidental sob a influência de diferentes substratos e recipientes. Revista Brasileira Fruticultura, Jaboticabal, v. 30, n. 2, p. 459-465, 2008. Disponível em: <http:// www.scielo.br/scielo.php?script $=$ sci_arttext\&pid $=$ S0100-29452008000200033 $>$. Acesso em: 20 jan. 2015.

PEREIRA, J. E. S.; BIANCHI, V. J.; DUTRA, L. F.; FORTES, G. R. L. Enraizamento in vitro do morangueiro (Fragaria xananassa Duchesne) em diferentes concentrações do meio MS. Ciência Rural, Santa Maria, v. 29, n. 1, p. 17-20, 1999. Disponível em: <http://www. scielo.br/pdf/cr/v29n1/a04v29n1.pdf $>$. Acesso em: 20 jan. 2015.

PEREIRA, J. E. S.; FORTES, G. R. L. Protocolo para a produção de material propagativo de batata em meio líquido. Pesquisa Agropecuária Brasileira, Brasília, v. 38, n. 9, p. 1035-1043, 2003. Disponível em: $<$ http://ainfo.cnptia.embrapa.br/digital/bitstream/ item/111544/1/11479.pdf $>$. Acesso em: 20 jan. 2015.
PEREIRA, M.; OLIVEIRA, A. L.; GONÇALVES, A. N.; ALMEIDA, M. Efeitos de substratos, valores de $\mathrm{pH}$, concentrações de AIB no enraizamento de estacas apicais de jabuticabeira [Myrciaria jabuticaba (Vell.) O. Berg.]. Scientia Forestalis, Piracicaba, n. 69, p. 84-92, 2005.

PINHO, R. S. Comparação entre ágar e amido como agentes geleificantes na micropropagação de batata doce Ipomoea batatas (L.) Lam. 2003. Dissertação (Mestrado em Agronomia/Horticultura) - Universidade Estadual Paulista, Botucatu.

SANTOS, J. A.; SILVA, C. R.; CARVALHO, J. G.; NASCIMENTO, T. B. Efeito do calcário dolomítico e nitrato de potássio no desenvolvimento inicial de mudas da bananeira 'Prata-Anã' (AAB), provenientes de cultura in vitro. Revista Brasileira de Fruticultura, Jaboticabal, v. 26, n. 1, p. 150-154, 2004. Disponível em: $\quad<$ http://www.scielo.br/scielo.php?pid=S010029452004000100040\&script=sci_arttext $>$. Acesso em: 22 jan. 2016.

SANTOS, M. R. A.; FERREIRA, M. G. R.; MARQUES, M. G. BAP e AIB no cultivo in vitro de Epidendrum ibaguense Kunth. Plant Cell Culture Micropropagation, Lavras, v. 6, n. 2, p. 90-98, 2010. Disponível em: <http:// abctp.org.br/revista/v6n2.pdf\#page=41>. Acesso em: 25 jan. 2015.

SCHOLTEN, H. J.; PIERIK, R. L. M. Agar as a gelling agent: differential biological effects in vitro. Scientia Horticulturae, Amsterdam, v. 77, n. 1-2, p. 109-116, 1998.

SCHUCH, M. W.; ERIG, A. C. Micropropagação de plantas frutíferas. In: FACHINELLO, J. C.; HOFFMANN, A.; NACHTIGAL, J. C. Propagação de plantas frutíferas. Brasília: Embrapa Informação Tecnológica, 2005. p. 155-173.

SILVA, D. M.; CARNEIRO, L. L.; MENDES, D. J.; SIBOV, S. T. Efeito das auxinas ácido naftaleno acético e ácido indolbutírico no desenvolvimento in vitro de plântulas de Cyrtopodium saintlegerianum Rchb. f. (ORCHIDACEAE). Enciclopédia Biosfera, Goiânia, v. 9 , n. 16, p. 852-860, 2013. Disponível em: <http://www. conhecer.org.br/enciclop/2013a/agrarias/efeito $\% 20$ das\%20auxinas.pdf $>$. Acesso em: 20 jan. 2015.

SOARES, J. D. R. Silício na micropropagação de orquídeas: características morfofisiológicas. 2009. Dissertação (Mestrado em Fisiologia Vegetal) Universidade Federal de Lavras, Lavras. 
SORACE, M.; FARIA, R. T.; DAMASCENO JÚNIOR, C. V.; GOMES, G. P.; BARBOSA, C. M.; VIEIRA, F. G. N.; SILVA, G. L.; TAKAHASHI, L. S. A.; SCHNITZER, J. A. Crescimento in vitro de Oncidium baueri (Orchidaceae) em diferentes concentrações de macronutrientes e sacarose. Semina: Ciências Agrárias, Londrina, v. 29, n. 4, p. 775-782, 2008. Disponível em: <http://www.uel.br/proppg/portal/pages/arquivos/ pesquisa/semina/pdf/semina_29_4_19_5.pdf>. Acesso em: 20 jan. 2015.
ZANDONÁ, A. P.; FARIA, R. T.; LONE, A. B.; HOSHINO, R. T. Substratos alternativos ao esfagno na aclimatização de plântulas de Arundina graminifolia alba (Orchidaceae). Revista Brasileira de Horticultura Ornamental, Londrina, v. 20, n. 1, p. 7-12, 2014. Disponível em: $<\mathrm{http}: / /$ rbho.emnuvens.com.br/rbho/ article/view/481/470>. Acesso em: 20 jan. 2015. 